\title{
Analysis of Internal, Market \& Economic Based Financial Performance Measurement of Some Selected Commercial Banks in Bangladesh
}

\author{
Shohana Rahman Lisa ${ }^{1}$, Ifrad Jahan ${ }^{2}$ \\ 1 (Department of Business Administration, Lecturer, Stamford University Bangladesh, Bangladesh) \\ 2 (Department of Business Administration, Lecturer, Stamford University Bangladesh, Bangladesh)
}

\begin{abstract}
The aim of this study is to investigate the financial performance of 10 commercial banks listed on Dhaka Stock Exchange. In this paper, financial performance has been measured by using three indicators. Internal-based performance measured by Return on Assets, Market-based performance measured by Tobin's $Q$ model (Price / Book value of Equity) and Economic-based performance measured by Economic Value adds. The correlation and multiple regression of annual time series data is used to find the impact of bank size, credit risk, operational efficiency and asset management on financial performance measured by the three indicators, The study rejected the null hypothesis and it is found that there exist statistically significant impact of bank size, credit risk, operational efficiency and asset management with ROA and Economic Value Added. On the other hand Tobin's $Q$ has insignificant impact on financial performance of commercial banks.
\end{abstract}

Keywords: Tobin's Q models, Economic Value add, Operational Efficiency, Asset management, Credit Risk.

\section{Introduction}

Financial sector of Bangladesh is dominated by the commercial banking system. Banking sector is one of the major sectors, which contributes significantly to the national economy. Hence a financially viable and healthy banking institution is a pre requisite for playing a vital role in the growth of the economy [1]. As one of the most important components of the financial system it forms the core of the money market and plays very pivotal role in mobilizing resources for productive investments in a country which in turn contributes to economic development. The efficiency of the sector is very important for overall development of the country.

For most businesses banking sector is preferred as an important source of financing. The common predetermining factor which leads to the financial performance research and discussion is that increasing financial performance will tend to improved functions and activities of the institutes [2]. It is often argued that there are three key principal factors to improve financial performance for financial institutions; the institution size, its asset management and the operational efficiency. There have been little published studies to explore the impact of these factors on the financial performance especially the commercial banks.

The proper inspiration of conducting this research is from that few studies have examined this issue or tried to better explain the performance of commercial banks in Bangladesh, those studies lead to use traditional financial ratio analysis and benchmarking to measure banks' performance, henceforth a comprehensive performance analysis framework that enrolls profitability and risk needs to be gradually developed to go beyond the traditional ratio analysis (M. Harsheh, 2012).

This paper aims to satisfy the following objectives:

\section{Objectives}

- To examine the financial performance based on the three indicators.

- To investigates the impact of financial performance by the bank size, credit risk, operational efficiency and asset management.

- To find out the any relationship among the independent variables with dependent variables.

\section{Literature Review}

In the global economy banks play as the backbone. It provides capital for innovation, infrastructure, job creation and overall prosperity. To find the results of a firm's policies and operations in economic terms, financial performance helps in many ways. Results are reflected in the firms ROA, ROE, EVA. These help us to evaluate how well a bank is using its resources to make a profit. Usually, by using a combination of financial ratio analysis, the financial performance of banks and other financial institutions has been measured. But ratios are calculated based on the accounting data rather than economic data.

[3] conducted a study in Pakistan where they found that those banks having higher total assets, total equity total operating fixed assets, they have better performance. [4] Used multiple linear regression technique 
for forecasting bank performance. Liquidity, credit risk, cost to income ratio, firm size and concentration ratio, were used as independent variables and ROA was used as dependent variables.

On a study, multiple regression analysis and correlations are used to investigate the financial performance of Omani Commercial banks where the ROA and the interest income are used as dependent variables and independent variables were the bank size, the asset management and the operational efficiency. A positive strong correlation between financial performance and operational efficiency and a moderate correlation between ROA and bank size is found and also found that there exist an impact of those independent variables on the financial performance as the F-stat is significant which is lower than the 5\% significant level (M. Tarawaneh, 2006). Bank size plays an important role to measure the profitability of the bank. ROE, Tobin's Q were used as a profitability measurement. They found that profitability is affected by the bank size, leverage ratio, asset management and investment [5].

[6] Studied the financial performance of Jordanian commercial banks where the ROA was used as a measure of banks performance and the bank size, asset management and operational efficiency were used as independent variables. They found that a strong negative correlation between ROA and banks size, a strong positive correlation between ROA and asset management ratio, and a negative weak correlation between ROA and operational efficiency. Most of the studies concerning company performance evaluation focus only on operational efficiency and operational effectiveness. It influences the survival of the company. A better effectiveness in term of management does not always mean that better efficiency and profitability of a company [7]. [8] Analyzed that banks are in a position to make a sustainable growth in respect of branches, employees, deposits, loans and advances, classified loan, net income and earnings per share during the period of 2007-2011 with some fluctuation. Banks only works with loan and deposit for this measurement of banks profitability is different from any other business [9].

[10] Have investigated the financial performance of five Palestinian commercial banks. They used three indicators: Internal-based, Market-based and Economic-based performance measures. Return on Assets, Tobin's Q model and Economic Value add methods have been used for measuring these three indicators where the independent variables were bank size, credit risk, operational efficiency and asset management. In the research correlation and multiple regression analysis have been applied. They found a significant impact. [11] Also studied based on the three indicators. They also found that dependent variables have significant impact on dependent variables on financial performance of Bangladeshi commercial banks. [12] Examined the impact of financial performance based on the ROE and ROD where independent variables were bank size, asset management and operational efficiency. They found significant relationship.

The paper is prepared to examine the linkage between financial performance measured by return on assets (ROA), along with price to book value ( Tobin's Q model ) and economic value add are used as performance proxy measures. In this paper Bank size (Total Asset), Asset management, operational efficiency and credit risk are used as independent variables to investigate their impact on the financial performance of ten private commercial banks in Bangladesh from the period of 2011-15.

\section{Banking Sector In Bangladesh}

For growth and success of projects in both industrial and developing countries financial services in particular are considered to be the key factor. The commercial banks are offering customer's superior international banking services inside and outside of Bangladesh. The commercial banking system dominates Bangladesh's financial sector.

Bangladesh Bank is the Central Bank of Bangladesh and the chief regulatory authority in the sector. The banking system is composed of four state-owned commercial banks, five specialized banks, thirty eight private commercial banks, one land development bank and nine foreign commercial banks. a specialized microfinance institution known as Grameen Bank, which revolutionized the concept of micro-credit and contributed greatly towards poverty reduction and the empowerment of women in Bangladesh. Now a day, private Banks are the highest growth sector in the Bangladesh because of miserable performances of government banks. For this private banks tend to offer better service and products for the customer (K. Rahman, 2013).

Agriculture, industries, power, transport, trade service, etc are the contributing sectors for economic development; banking sector also has a contribution to the economic development. Here shows the contribution of banking sectors as percentage of GDP). 
Table 1: Contribution of Banking Sectors as Percentage of GDP

\begin{tabular}{|c|c|}
\hline Year & Contribution as percentage of GDP \\
\hline $1985-86$ & $1.69 \%$ \\
\hline $1993-94$ & $2.09 \%$ \\
\hline $1997-98$ & $2.00 \%$ \\
\hline $2006-07$ & $4.74 \%$ \\
\hline $2009-10$ & $3.15 \%$ \\
\hline $2012-13$ & $10.87 \%$ \\
\hline $2013-14$ & $10.53 \%$ \\
\hline $2014-15$ & $10.94 \%$ \\
\hline
\end{tabular}

Source: Bangladesh Economic Review

(F. Khatun, 2016) Research Director, Centre for Policy Dialogue (CPD) showed that Profitability, measured by return on asset and return on equity, has been negative for the state-owned banks (SCBs). But it is positive for private commercial banks but at very low. Similar performance is observed in non-performing loans. Though the share of NPL to total loans in SCBs has slightly declined in September 2015 from June 2014, the rate is still as high as $21.82 \%$. On the other hand, NPL in private commercial banks (PCBs) and foreign commercial banks (FCBs) have increased. It will be challenging for the SCBs to implement of BASEL III requirements where capital adequacy ratio need to be increased to $12.5 \%$ of their risk-weighted assets by 2019 . But on September 2015 , capital adequacy ratio of SCBs was only $6.2 \%$, which is so much lower.

\section{Hypothesis Development}

In developing the hypothesis, our main goal is to find whether there exist significant impact between each independent variable and the dependent variable, and to assess the significance impact of the independent variables used together on the dependent variable(s), the null and alternative hypothesis are:

H0: There exist an insignificant impact of size, credit risk, asset management and operational efficiency on financial performance of commercial banks of Bangladesh.

H1: There exist a significant impact of size, credit risk, asset management and operational efficiency on financial performance of commercial banks of Bangladesh.

\subsection{Sample of the study}

\section{Methodology}

The sample of the study consists of the 10 commercial banks listed on Dhaka stock exchange. Annual Time series data for independent- dependent variables were extracted from banks' annual audited financial statements from the period 2011-15.

\subsection{Regression models}

To assess the financial performance of the commercial banks, we developed three models; each consists of one dependent variable and four identical independent variables. We used the ROA as an internal financial performance indicator, the Tobin's Q model (Price / Book) as a market financial performance indicator and finally the Economic value add as an economic financial performance indicator. The table below shows the variables:

Table 2: Explanatory Variables

\begin{tabular}{|l|l|l|l|}
\hline \multicolumn{1}{|c|}{ Dependent Variables } & \multicolumn{1}{|c|}{ Description } & \multicolumn{1}{|c|}{ Independent Variables } & \multicolumn{1}{c|}{ Description } \\
\hline ROA & Net Income / Total Assets & Bank Size & LOG ( Total Assets) \\
\hline Tobin's Q & $\begin{array}{l}\text { Market value of bank / Book Value of } \\
\text { equity }\end{array}$ & Credit Risk (CR) & $\begin{array}{l}\text { Reserves for doubtful loans / } \\
\text { Credit facilities }\end{array}$ \\
\hline Economic Value add & $\begin{array}{l}\text { Net Operating Profit After Taxes } \\
\text { (NOPAT) - (Capital * Cost of Capital). }\end{array}$ & Operational Efficiency (OE) & $\begin{array}{l}\text { Totaloperating expense / net } \\
\text { interest income }\end{array}$ \\
\hline & \multicolumn{1}{|l|}{ Asset management (AM) } & Operating income / total assets \\
\hline
\end{tabular}

\subsection{Correlation and regression Results for model I}

\section{Data Analysis And Result}

In Model 1 we have found out the correlation and regression between ROA and the four independent variables Bank size (Total Asset), Credit risk (CR), Operational efficiency (OE), and Asset management (AM).

Table 3: Correlation Matrix

\begin{tabular}{|l|l|l|l|l|l|}
\hline & \multicolumn{1}{|c|}{ ROA } & \multicolumn{1}{|c|}{ Bank Size } & Credit Risk & OE & AM \\
\hline ROA & 1 & & & & \\
\hline Bank Size & 0.154707681 & 1 & & & \\
\hline Credit Risk & -0.204410343 & -0.169929446 & 1 & & \\
\hline OE & -0.090873428 & -0.242126479 & 0.023160871 & 1 & \\
\hline AM & 0.495785782 & -0.055338228 & -0.559367353 & 0.078138041 & 1 \\
\hline
\end{tabular}


Referring to the correlation matrix, we find

- A less positive correlation between the dependent variable ROA and the independent variable banks' size measured by the Logarithm of total assets of about $(+0.1547)$.

- A less negative correlation was found between ROA and Credit Risk (-0.2044).

- Operational efficiency found to be negatively-weak correlated with ROA of about(-0.0909).

- A positive correlation with Asset management of (+ 0.496).

Table 4: Regression Statistics

\begin{tabular}{|l|l|}
\hline Multiple R & 0.553347626 \\
\hline R Square & 0.306193595 \\
\hline Adjusted R Square & 0.244521915 \\
\hline Standard Error & 0.057855385 \\
\hline Observations & 50 \\
\hline
\end{tabular}

ANOVA Table

\begin{tabular}{|c|c|c|c|c|c|}
\hline & df & SS & MS & $\mathrm{F}$ & Significance F \\
\hline Regression & 4 & 0.066474929 & 0.016618732 & 4.964897876 & 0.002113019 \\
\hline Residual & 45 & 0.150626049 & 0.003347246 & & \\
\hline Total & 49 & 0.217100978 & & & \\
\hline & Coefficients & Standard Error & t Stat & P-value & Lower 95\% \\
\hline Intercept & -0.428991484 & 0.223117169 & -1.922718386 & 0.060858417 & -0.878372524 \\
\hline Bank Size & 0.062394045 & 0.04218775 & 1.478961186 & 0.146117256 & -0.022576444 \\
\hline Credit Risk & 1.351167817 & 1.211127598 & 1.115627965 & 0.270503734 & -1.088168346 \\
\hline $\mathrm{OE}$ & -0.002549388 & 0.003427646 & -0.74377223 & 0.460880351 & -0.009453021 \\
\hline AM & 2.710299427 & 0.678284548 & 3.995814789 & 0.000236327 & 1.344164241 \\
\hline
\end{tabular}

Referring to regression analysis, we find the adjusted R-square to be $24.45 \%$, so we can conclude that $24.45 \%$ of the variation in the dependent variable (ROA) is explained by the independent variables. This implies somehow low explanatory power for the whole regression. As long as the F-stat equals 4.9 and is significant (less than 5\%), we reject the null Hypothesis. So there exists a significant impact of Asset size, Credit risk, operational Efficiency and Asset management on internal financial performance of commercial banks measured by ROA.

The equation is: $\mathrm{ROA}=-.4289+.0623 \mathrm{SIZE}+-1.3512 \mathrm{CR}-.00254 \mathrm{OE}+2.7102 \mathrm{AM}+\mathrm{e}$

To assess the significance of each independent variable on the dependent variable ROA, we use the t-test with the significance factors. Asset size, operational efficiency and Credit risk found to be significant and affect ROA as their t-sig are less than 5\%. Asset management has insignificant effect on ROA.

\subsection{Correlation and Regression Results for model II}

In Model II we have found out the correlation and regression between Tobin's Q and the four independent variables Bank size (Total Asset), Credit risk (CR), Operational efficiency (OE), and Asset management (AM).

Table 5: Correlation Matrix

\begin{tabular}{|l|l|l|l|l|l|}
\hline & \multicolumn{1}{|c|}{ Tobin's Q } & \multicolumn{1}{c|}{ Bank Size } & \multicolumn{1}{c|}{ Credit Risk } & \multicolumn{1}{c|}{ OE } & AM \\
\hline Tobin's Q & 1 & & & & \\
\hline Bank Size & -0.197322825 & 1 & & & \\
\hline Credit Risk & -0.195597149 & -0.169929446 & 1 & & \\
\hline OE & -0.089858999 & -0.242126479 & 0.023160871 & 1 & \\
\hline AM & 0.301801364 & -0.055338228 & -0.559367353 & 0.078138041 & 1 \\
\hline
\end{tabular}

Analyzing the second model, we find the following correlations of the Independent variables with the market performance of banks measured by Tobin's Q as the following: 
- A weak negative correlation with the bank size (-.1973),

- A weak negative correlation with credit risk (-0.1955).

- A very weak negative correlation with operational efficiency (-0.0898).

- A weak positive correlation with asset management ratio (+ 0.3018).

Table 6: Regression Results

\begin{tabular}{|l|l|}
\hline \multicolumn{2}{|c|}{ Regression Statistics } \\
\hline Multiple R & 0.394364785 \\
\hline R Square & 0.155523584 \\
\hline $\begin{array}{l}\text { Adjusted R } \\
\text { Square }\end{array}$ & 0.080459013 \\
\hline Standard Error & $2.26955 \mathrm{E}-07$ \\
\hline Observations & 50 \\
\hline
\end{tabular}

\begin{tabular}{|l|l|l|l|l|l|}
\hline \multicolumn{7}{|c|}{ ANOVA Table } \\
\hline & \multicolumn{1}{|c|}{ df } & \multicolumn{1}{c|}{ SS } & \multicolumn{1}{c|}{ MS } & F & Significance F \\
\hline Regression & 4 & $4.26876 \mathrm{E}-13$ & $1.06719 \mathrm{E}-13$ & 2.071864034 & 0.100314199 \\
\hline Residual & 45 & $2.31789 \mathrm{E}-12$ & $5.15086 \mathrm{E}-14$ & & \\
\hline Total & 49 & $2.74476 \mathrm{E}-12$ & & & \\
\hline \multicolumn{7}{|c|}{} \\
\hline
\end{tabular}

Looking at regression analysis we find that the explanatory power of the whole second regression model is about $8.04 \%$, where at the same time, the F-stat is 2.0718 and is more than 5\%, which is Insignificant. As a result, we reject the alternative hypothesis. So there exist an insignificant impact of Asset size, credit risk, operational Efficiency and Asset management on market financial performance of commercial banks measured by Tobin's' Q model. Thus, we can predict the average Tobin's Q (market-based performance indicator) with about $8.04 \%$ explanatory power by the following model.

Tobin's Q: -.00000012- .000000272 BSIZE -.000000258 CR + 0.0 OE + 0.00000039AM + e

To assess the significance of each independent variable on the dependent variable Tobin's Q. asset management is the only variable that found to be significant the other variables, operational efficiency, Asset size and credit risk are found to be insignificant and doesn't individually affect Tobin's Q as their t-sig are more than 5\%.

\subsection{Correlation and Regression Results for model III}

Table 7: Correlation Matrix

\begin{tabular}{|l|l|l|l|l|c|}
\hline & \multicolumn{1}{|c|}{ EVA } & \multicolumn{1}{|c|}{ Bank Size } & \multicolumn{1}{c|}{ Credit Risk } & OE & AM \\
\hline EVA & 1 & & & & \\
\hline Bank Size & 0.323663728 & 1 & & & \\
\hline Credit Risk & -0.328355083 & -0.169929446 & 1 & & \\
\hline OE & -0.084140916 & -0.242126479 & 0.023160871 & 1 & \\
\hline AM & 0.141637682 & -0.055338228 & -0.559367353 & 0.078138041 & 1 \\
\hline
\end{tabular}

Analyzing the third model, I find the following correlations of the Independent variables with the Economic performance of banks measured by EVA as the following:

- A weak positive correlation with the bank size (+ 0.3236). 
- A weak negative correlation with credit risk (-.3283).

- A very weak negative correlation with operational efficiency (-0.0841).

- A weak positive correlation with asset management ratio (+0.141).

Table 8: Regression Results

\begin{tabular}{|l|l|}
\hline \multicolumn{2}{|c|}{ Regression Statistics } \\
\hline Multiple R & 0.426412761 \\
\hline R Square & 0.181827843 \\
\hline $\begin{array}{l}\text { Adjusted R } \\
\text { Square }\end{array}$ & 0.109101429 \\
\hline Standard Error & 3375.076324 \\
\hline Observations & 50 \\
\hline
\end{tabular}

\begin{tabular}{|l|l|l|l|l|c|}
\hline \multicolumn{7}{|c|}{ ANOVA Table } \\
\hline & \multicolumn{1}{|c|}{ df } & SS & MS & F & Significance F \\
\hline Regression & 4 & 113918799.8 & 28479699.95 & 4.500162359 & 0.00505695428 \\
\hline Residual & 45 & 512601308.8 & 11391140.2 & & \\
\hline Total & 49 & 626520108.6 & & & \\
\hline
\end{tabular}

\begin{tabular}{|l|l|l|l|l|l|}
\hline & Coefficients & Standard Error & t Stat & P-value & Lower 95\% \\
\hline Intercept & -19909.63535 & 13015.8581 & -1.52964447 & 0.133104638 & -46124.91887 \\
\hline Bank Size & 4701.056738 & 2461.082544 & 1.910158093 & 0.062498439 & -255.8178814 \\
\hline Credit Risk & -118629.8673 & 70652.85467 & -1.679052713 & 0.100073466 & -260932.0192 \\
\hline OE & -16.53401947 & 199.9566113 & -0.082688036 & 0.934466321 & -419.267302 \\
\hline AM & 26.47870859 & 39568.69587 & 0.000669183 & 0.999469027 & -79668.96457 \\
\hline
\end{tabular}

Looking at regression analysis we find that the explanatory power of the whole third regression model is about $10.91 \%$ as evidenced by the adjusted R-square, where at the same time, the F-stat is 4.50 and is less than 5\%, which is significant. This implies the acceptance of the alternative hypothesis claiming that there exist an impact of Asset size, credit risk, operational efficiency and asset management on economic financial performance of commercial banks measured by EVA.

The equation is: $\mathrm{EVA}=-19909.63-4701.056 \mathrm{BSIZE}+-118629 \mathrm{CR}+-.16 .53 \mathrm{OE}+26.47 \mathrm{AM}+\mathrm{e}$

To pinpoint the significance of each independent variable on the dependent variable EVA, the t-test with the significance factors, Asset size, Credit risk, operational efficiency and asset management found to be significant and affect EVA as their t-sig are less than $5 \%$.

\section{Findings And Conclusion}

The findings of the study are partially consistent with theoretical expectations. We have wanted to find the impact of bank size, credit risk, operational efficiency and asset management on financial performance measured by the three indicators. Internal-based performance measured by Return on Assets, Market-based performance measured by Tobin's Q model (Price / Book value of Equity) and Economic-based performance measured by Economic Value adds. The data set covers the period 2011-2015. In our study we have taken ten private commercial banks from the 63 banks for our analysis. We found that there is low positive correlation between the Bank size and ROA, Bank size and Tobin's Q and also bank size and EVA. Other variables have low negative relationship with independent variables. The independent variables as a whole can explain only $24.05 \%, 8.04 \%$ and $10.91 \%$ variation of the dependent variable in Model I, II, and III consequently. The study rejected the null hypothesis and it is found that there exist statistically significant impact of bank size, credit risk, operational efficiency and asset management with ROA and Economic Value Added. On the other hand Tobin's Q has insignificant impact on financial performance of commercial banks. By this study managers could take decision and pay more attention in the three indicators to enhance their financial performance. 


\section{Journal Papers:}

\section{References}

[1]. M. J.A.Siddikee, S.Parvin, andM.S.Hossain, Effect of Net Income on Total Assets of Financial Organizations,Journal of Science and Technology, 2013, 112-117.

[2]. M.Tarawaneh, A comparison of financial performance in the banking sector evidence from Omani commercial banks, International research journal of finance and banking, Issue 3,2006 .

[3]. F. Abbas, M.Tahir, and M.Rahman, A Comparison of Financial Performance in the Banking Sector: Some Evidence from Pakistani Commercial Banks, Journal of Business Administration and Education, Volume 1, 2012, 1-14.

[4]. N. Bakar, and I. M. Tahir, Applying multiple linear regression and neural network to predict bank performance, International Business Research, 2 (4), 2009, 176-183.

[5]. M. A. Siddiqui, and A. Shoaib, Measuring performance through capital structure: Evidence from banking sector of Pakistan, African Journal of Business Management, 2011.

[6]. A. A. Almazari,Financial Performance Evaluation of Some Selected Jordanian Commercial Banks, International Research Journal of Finance and Economic, 2011.

[7]. C. Ta Ho, and D. Song Zhu, Performance measurement of Taiwan's commercial banks, International Journal of Productivity and Performance Management, Vol. 53 Issue: 5, 2004, 425 - 434.

[8]. M. R. Uddin, and J.F. Bristy, Evaluation of Some Private Commercial Banks in Bangladesh from Performance Perspectives, International Journal of Managing Value and Supply Chains (IJMVSC) Vol. 5, No. 4, 2014.

[9]. N. Jahangir, S. Shill, and M.J.A. Haque, Examination of Profitability in the Context of Bangladesh Banking Industry, ABAC Journal, Vol. 27, 2007, 36-46.

[10]. Alkhatib\&M. Harsheh, Financial Performance of Palestinian Commercial Banks, International Journal of Business and Social Science, Vol. 3 No. 3, 2012, 175- 184.

[11]. R.A. Karim, and T. Alam, An Evaluation of Financial Performance of Private Commercial Banks in Bangladesh: Ratio Analysis, Journal of Business Studies Quarterly, Vol. 5, 2013, 65-77.

[12]. M.H.M. Adam, Evaluating the Financial Performance of Banks Using Financial Ratios-A Case Study of Erbil Bank for Investment and Finance, European Journal of Accounting Auditing and Finance Research, Vol. 2, No. 6, 2014, 162177. 